\title{
The Curriculum Construction of "Biogas Production Engineering” Aimed to the Innovative Talent Cultivation
}

\author{
Xinyuan Liu, Nan Wu, Dengchao Jin, Lei Yang \\ College of Engineering and Technology \\ Tianjin Agricultural University \\ Tianjin, 300384, China \\ e-mail: liuxinyuan11@163.com
}

\begin{abstract}
In this paper, the course construction of "Biogas Production Engineering" in the course system of New Energy Science and Engineering specialty featured with biomass energy development and utilization is discussed. In order to promote the innovative talent training, the classroom teaching, the experiment teaching and the examination system are primarily constructed. The teaching content and method are set to adapt to the undergraduate student. The course construction of "Biogas Production Engineering" is achieved by designing task-based teaching scheme, establishing practice course experiment and procedural evaluation system. The study enthusiasm of the students will be improved and the innovative ability of the students will be promoted by the study of "Biogas Production Engineering".
\end{abstract}

Keywords - course construction; innovative talent cultivation; classroom teaching; experiment teaching; examination system

\section{CURRICULUM INTRODUCTION}

Innovational and enterprising talents have the characteristics of independence, pioneering innovation, selfcontrol and interoperability. The cultivation of the innovational and enterprising talents is one of the education points for most of the undergraduate colleges, and it should be implemented and continuously deepened [1]. In accordance with the requirements for cultivating creative personnel, the cultivation objectives for New Energy Science and Engineering specialty under the background of agricultural engineering discipline in agricultural colleges are as following: with the demand of energy talented person for the modern urban agriculture as the guidance, the practical engineering and technical personnel is cultivated for the development, design, management and utilization of biomass energy [2]. In the curriculum system, the "Biogas Production Engineering" covers the basic principle of biogas fermentation system, process design, technology development, operation management, and other basic knowledge and practical skills; its teaching content is one of the core requirements of this professional training target. Thus, the "Biogas Production Engineering" is one of the main courses in the curriculum system for the New Energy Science and Engineering specialty with the biomass energy development as feature.
At present, the "Biogas Production Engineering" has a total of 32 class hours, including 26 classroom teaching hours and 6 experimental hours. With lecture teaching as the main teaching way, the students' participation degree is low and the learning enthusiasm is hard to inspire, which are not benefit for the cultivation of innovative talents. This article tries to increase the teacher and students communication in class from the aspects of curriculum teaching, experiment teaching and examination system. In order to adapt to the creative talent training requirement, the "Biogas Production Engineering" is constructed by the design of task-based teaching plan, the set up the return-to-practiced course experiment and procedural evaluation system.

\section{CLASSROOM TEACHING MODEL}

\section{A. Teaching Contents}

There are many kinds of biogas production technologies in the scientific studies and industrial fields, the diversities are reflected on the fermentation scales of the biogas digester, biogas production technologies and its own application domain. Besides, the new technology, new process and new equipment continue to be developed and applied [3]. Therefore, the biogas production is a new discipline with rapid development rate. The classroom teaching of "Biogas Production Engineering" is divided into three levels, from the research level (including the theoretical basis and application basis), household level to the engineering level, which is useful to the combination of biogas production knowledge and its corresponding applications field. The three-level classroom teaching method is helpful in the formation of subjective understanding, and guiding students to build the thinking mode of flexible use of the knowledge. Based on the purpose of the innovative talent training, the latest research results is widely referenced in the classroom teaching process in order to state the research level of the biogas production technology. A large number of engineering application examples is listed to illustrate application status of biogas production technology in biogas engineering. The classroom teaching will help students to develop thinking and enrich their knowledge.

Considering the professional orientation towards agricultural science and engineering course, the book of 
"Biogas Technology and Its Application" (ISBN: 978750256936) published from Chemical Industry Press is chosen as the main reference materials. And also, the book of "Methane Fermentation" (ISBN: 9787122195043) and "Design and Application for Large and Medium-sized Methane Project" (ISBN: 9787122163769) are referenced in the teaching activities. Moreover, the latest research achievements in recent years (such as papers, books, etc.) are introduced in the classroom teaching. The teaching levels, contents and teaching hour schedules are scientifically arranged, which is shown in Table I.

TABLE I. THE TEACHING LEVELS, CONTENTS AND TEACHING HOUR SCHEDULES OF "BIOGAS PRODUCTION ENGINEERING"

\begin{tabular}{|c|c|c|}
\hline Levels & contents & $\begin{array}{c}\text { Teaching } \\
\text { hours }\end{array}$ \\
\hline Background & Research and development history & 1 \\
\hline \multirow{3}{*}{$\begin{array}{l}\text { Research } \\
\text { (Theory) }\end{array}$} & Biogas fermentation theory & 1 \\
\hline & Microbiological basis of biogas production & 2 \\
\hline & $\begin{array}{l}\text { The representation method of organic matter } \\
\text { and methane yield calculation method }\end{array}$ & 2 \\
\hline \multirow{5}{*}{$\begin{array}{l}\text { Research } \\
\text { (Application) }\end{array}$} & Biogas production process & 2 \\
\hline & Biogas fermentation conditions & 2 \\
\hline & The influence factors of biogas production & 2 \\
\hline & Dry fermentation technology & 1 \\
\hline & $\begin{array}{l}\text { Anaerobic fermentation hydrogen production } \\
\text { technologies }\end{array}$ & 1 \\
\hline \multirow{2}{*}{$\begin{array}{l}\text { Household } \\
\text { utilization }\end{array}$} & $\begin{array}{l}\text { Types and design calculation of biogas } \\
\text { digester }\end{array}$ & 2 \\
\hline & $\begin{array}{l}\text { Household biogas digester construction and } \\
\text { operation management }\end{array}$ & 2 \\
\hline \multirow{3}{*}{$\begin{array}{l}\text { Engineering } \\
\text { utilization }\end{array}$} & Technological process of biogas engineering & 3 \\
\hline & Design calculation of the biogas engineering & 3 \\
\hline & $\begin{array}{l}\text { Construction and operation management of } \\
\text { biogas engineering }\end{array}$ & 2 \\
\hline
\end{tabular}

\section{B. Teaching method}

Under the traditional lecture teaching method, the active attitude and participation enthusiasm of the students are poor, leading to bad inattention and learning effect. In order to improve the teaching efficiency, teachers should lead the student to input and participate in the teaching process, and impose parts of learning pressure to students. Task teaching method, with the learning task as the basic unit of teaching, is an effective method to mobilize students learning enthusiasm and innovation by asking the student to complete the prescribed learning task [4]. During the implementation of ask teaching method, the students are the subject to complete learning task, so they are required to search literature, integrate ideas, and develop innovation independently. In order to complete the teaching content following the syllabus in the limited class hour, the classroom teaching method of this course gives priority to the teacher's teaching, and the task teaching takes subsidiary function, so that the overall teaching plan could be controlled.

In the implementation of task teaching method, the interest, ability and knowledge level of students must be considered, and the teaching scope and effect must also be guaranteed. Therefore, the establishment of specific task point scientifically is important for the implementation of task teaching method. The specific task point should be closely linked to the engineering practice and the real life for the course of "Biogas Production Engineering", and it should basically cover the main content of this course. The specific teaching task point is shown in Table II.

\begin{tabular}{|c|c|}
\hline TABLE II. & $\begin{array}{l}\text { THE SPECIFIC TEACHING TASK POINT FOR THE COURSE OF } \\
\text { "BIOGAS PRODUCTION ENGINEERING" }\end{array}$ \\
\hline Number & Name of specific teaching task point \\
\hline 1 & Comparison of various biogas production process \\
\hline 2 & $\begin{array}{c}\text { The influence of temperature, hydraulic retention time and } \\
\text { organic loading on biogas fermentation and } \\
\text { microorganisms }\end{array}$ \\
\hline 3 & $\begin{array}{c}\text { The influence of ammonium, } \mathrm{S}^{2-} \text { and } \mathrm{SO}_{4}{ }^{2-} \text { in feedstock on } \\
\text { the biogas production and utilization }\end{array}$ \\
\hline 4 & $\begin{array}{l}\text { Classification and features of water pressure biogas } \\
\text { digester }\end{array}$ \\
\hline 5 & Operation and management of household biogas digester \\
\hline 6 & $\begin{array}{l}\text { Pretreatment process of the biogas engineering and its } \\
\text { design calculation }\end{array}$ \\
\hline 7 & $\begin{array}{l}\text { The characteristics of the up-flow anaerobic sludge blanket } \\
\text { and its design }\end{array}$ \\
\hline 8 & $\begin{array}{c}\text { Post-treatment process of the biogas engineering and its } \\
\text { design calculation }\end{array}$ \\
\hline
\end{tabular}

In practice, students can be divided into different teaching task group (5-6 members in each group) firstly and assigned teaching tasks point intensively. And then each team is given enough time to consult the materials and make PowerPoint (PPT). In order to guarantee the implementation of the teaching method, the completion results of teaching task point should be brought into the assessment system. The member in each group is selected randomly to display the PPT when the relevant knowledge is involved in the lectures teaching, and each group has $10-15$ min to introduce their investigation results.

\section{EXPERIMENTAL TEACHING PATTERN}

Course experiment is an important step in students' creativity cultivation by asking questions, analyzing and solving problems [5]. According to the engineering feature of "Biogas Production Engineering", the experiment content should be close to the engineering practice, and it must be paid attention to students' practical ability and reflected the current development level of science and technology. Experiment courses should be open and participative, which is beneficial to cultivate the students' interest, experimental skills and independent scientific research ability.

Experiment contents with high representative and strong operability are chosen in experimental curriculum, and the experimental method should be accord to the national standard. The new technology, new process, new method is encouraged to improve the link of experiment and engineering practice. The main experiments involved in the biogas production are the determination of key parameters, the operation of the typical fermentation device and automatic control, as well as batch experiment for methane production, etc. 
The book of "Biogas Fermentation Experiment Course" (ISBN: 7122180867) published in Chemical Process Press is the main reference materials. Caused by a lack of class tension and experimental conditions, three return-to-practiced experiments of "Gas Chromatographic analysis method for methane content determination" (verification), "The structure and automatic run of UASB fermentation system" (demonstration), and "The startup of anaerobic fermentation process treating organic matter" (comprehensive), are selected in the experimental design.

\section{Evaluation SYSTEM CONSTRUCTION}

Evaluation system is the baton of a course, which guides students to pay attention to the knowledge that need to master using scores guide. A suitable assessment system will improve the teaching effect of the whole course and coincide with innovative talent cultivation. Common evaluation system mainly includes the projects of daily performance and paper exams, which is hard to response of the comprehensive quality and the overall study effect for the students. Usually, the daily performance, on the aspects of learning attitude, basic situation of classroom participation and so on, are obtained by observation of teachers. In addition, the standardized form of paper exam could only get the learning results and ignore the learning process [6], which could not fully reflect the students' comprehensive ability. Teachers should grasp the initiative in the process of teaching and get the students to participate in the classroom and experiment teaching activities. Therefore, in order to improve the students' participation in teaching and in terms of performance, the teaching program should be carefully reset and the evaluation system should be optimized. To the exam system optimization, the concept of paper-score-oriented must give way to turn into the concept of learning-processoriented. The procedural evaluation system will pay attention to students' comprehensive performance and abilities, such as the data processing ability, practice ability and innovation ability, learning attitude and expression ability, and etc.

This paper established a procedural evaluation system consisted of the classroom assessment, the experimental examination, thesis evaluation, assessment of knowledge and the teaching task assessment. This evaluation system covers a variety of evaluation methods and multiple examination forms for the final score determination. The specific evaluation form, evaluation content, evaluation point and score proportion are shown in Table III.

TABLE III. THE PROCEDURAL EVALUATION SYSTEM OF “BIOGAS PRODUCTION ENGINEERING"

\begin{tabular}{|c|c|c|c|c|}
\hline $\begin{array}{c}\text { Evaluation } \\
\text { program }\end{array}$ & Evaluation form & Evaluation content & Evaluation key point & Score proportion \\
\hline $\begin{array}{l}\text { Classroom } \\
\text { assessment }\end{array}$ & $\begin{array}{l}\text { Roll call; Asking questions; } \\
\text { Observation }\end{array}$ & $\begin{array}{l}\text { Classroom performance; Class } \\
\text { attendance; Participation situation }\end{array}$ & Learning process and attitude & $10 \%$ \\
\hline $\begin{array}{l}\text { Experimental } \\
\text { examination }\end{array}$ & $\begin{array}{l}\text { Experimental operation; } \\
\text { Experimental Report }\end{array}$ & $\begin{array}{l}\text { Enthusiasm in experiment; } \\
\text { Practical ability; Teamwork; }\end{array}$ & $\begin{array}{l}\text { Operational Ability; } \\
\text { Data analysis ability; }\end{array}$ & $30 \%$ \\
\hline $\begin{array}{l}\text { Thesis } \\
\text { evaluation }\end{array}$ & Course thesis & $\begin{array}{l}\text { Standardization in writing; } \\
\text { integrity and innovation in } \\
\text { writing content; Conception } \\
\text { flexibility; Rich and bright color }\end{array}$ & $\begin{array}{l}\text { Knowledge comprehensive } \\
\text { ability; Creative thinking ability; } \\
\text { Knowledge application ability }\end{array}$ & $30 \%$ \\
\hline $\begin{array}{l}\text { Knowledge } \\
\text { assessment }\end{array}$ & Closed-book exam & $\begin{array}{c}\text { Accuracy and professionalism in } \\
\text { question answering }\end{array}$ & $\begin{array}{l}\text { Mastering degree of field } \\
\text { knowledge points }\end{array}$ & $15 \%$ \\
\hline $\begin{array}{l}\text { Teaching } \\
\text { task } \\
\text { assessment }\end{array}$ & Academic report & $\begin{array}{c}\text { Content innovation and integrity; } \\
\text { Aesthetics; Hierarchy; } \\
\text { organization; }\end{array}$ & $\begin{array}{l}\text { Academic reporting ability; } \\
\text { Expression ability; } \\
\text { Knowledge integration ability; } \\
\text { Innovation ability }\end{array}$ & $15 \%$ \\
\hline
\end{tabular}

All the activities of learning are evaluated by the assessment system in Table III, and the learning pressure is back to students. The study attitude would be more positive and the teaching effect will be improved accordingly by the implementation of the evaluation system. Therefore, the evaluation system is conducive to improve students' study enthusiasm and train students' innovative ability, and it also plays an important role in innovative talent cultivation.

\section{CONCLUSIONS}

Based on the demand of innovative personnel cultivation, the course of "Biogas Production Engineering" in the course system of New Energy Science and Engineering specialty is constructed in this paper. The classroom teaching, experiment content and evaluation system are constructed according to the course orientation. In order to improve the students' interest on learning and develop their innovative thinking, the curriculum is constructed as follows:

(1) The task-based teaching plan is implemented scientifically to make the learning pressure back to students, and the learning enthusiasm and innovative consciousness are stimulated by completing the teaching task.

(2) The course experiment is established laying emphasis on the practice and engineering. The representative and operational experiment are selected to improve the students' practical ability and independent scientific research ability. 
(3) The procedural evaluation system consists of classroom assessment, the experimental examination, thesis evaluation, assessment of knowledge and the teaching task assessment is built to guarantee the teaching effect.

\section{ACKNOWLEDGMENT}

Authors are grateful to the financial support from the 2017 Guide and Development Program of College Teachers Education Reform and Innovation in Tianjin Agricultural University (No. 20170104).

\section{REFERENCES}

[1] Z. Q. Gu and Y. Liu, "Logistics management specialty "logistics" course exam reform based on innovative entrepreneurial talent training,"
Economic Vision (underpart), Beijing, vol. 07, pp. 166-168, 2013. (In Chinese)

[2] J. X. Peng, "Positioning and constructioin of New Energy Science and Engineering sepecialty in Agricultural Universities," Journal of Tianjin Agricultural University, Tianjin, vol. 22, pp. 62-64, 2015. (In Chinese)

[3] Noke Dachiya, Methane fermentation, 1rd ed. Beijing: Chemical Industry Press, 2014, pp.1-30. (In Chinese)

[4] L.Y. Chen, "Task teaching method and its practice in college English teaching reform research," Journal of Luohe Vocational and Technical College, Louhe, vol. 03, pp. 82-84, 2016. (In Chinese)

[5] F. Kong, Z. L. Xue, C. Y. Yang, M. Wei, S. H. Qian, S. M. Ye, "Teaching reform of environmental microbiology experimental," Journal of Science of Teachers' College and Unviersity, QiQiHaEr, vol. 36, pp. 97-99, 2016. (In Chinese)

[6] Y. Gao, Y. Wang, Y. Q. Xu, J. Y. Hu, L. He, "Reform and exploration of "Food Biotechnology" course examination system," Journal of Anhui Agricultural Science, Hefei, vol. 12, pp. 7591-7592, 2012. (In Chinese) 